\title{
Topical Clover Flower Honey Administration Accelerated Wound Healing in Swiss Webster Mice
}

\author{
Hans Kristian*, Iwan Budiman**, Stella T Hasianna*** \\ *Faculty of Medicine Maranatha Christian University \\ *Department of Nutrition Faculty of Medicine Maranatha Christian University \\ ${ }^{* * *}$ Department of Physiology Faculty of Medicine Maranatha Christian University \\ Jl. Prof. Drg. Suria Sumantri MPH No.65 Bandung 40164 \\ Email : hans_kristian17@yahoo.com
}

\begin{abstract}
Clover flower honey is a herbal therapy used as an alternative wound treatment. The objective of this study is to determine the effect of clover flower honey in accelerating incision wound healing, enhancing reepithelization degree, increasing fibroblast density, and collagen.This is a true experimental research, using 25 mice divided into 5 groups $(n=5)$; positive control group (feracrylum 1\%), negative control group (aquadest), 100\% honey group, $50 \%$ honey group, and $25 \%$ honey group. Wound healing activity is measured macroscopically with calipers, dan microscopically through pathological anatomy preparations to observe reepithelization degree and collagen density. This study shows wound incision lengths were different significantly between clover flower honey 100\%, 50\%, and $25 \%$ compared to aquadest $(p \leq 0.05)$, and feracrylum 1\% ( $p \leq 0.05)$. Reepithelization degree, fibroblast and collagen density measurements between Clover flower honey 100\%, 50\%, and 25\% are different significantly compared with aquadest $(p \leq 0.05)$, and only the 100\% honey group is different significantly with feracrylum $1 \%(p \leq 0.05)$. This study concludes that topical clover flower honey administration accelerates wound healing, increases reepithelization degree, fibroblast density, and collagen degree.
\end{abstract}

Keywords : wound healing, reepithelization degree, fibroblast density, collagen density, Clover flower honey 


\title{
Pemberian Madu Bunga Clover Secara Topikal Mempercepat Penyembuhan Luka pada Mencit Swiss Webster
}

\author{
Hans Kristian*, Iwan Budiman**, Stella T Hasianna*** \\ *Fakultas Kedokteran Universitas Kristen Maranatha \\ ** Bagian Ilmu Gizi, Fakultas Kedokteran, Universitas Kristen Maranatha \\ *** Bagian Fisiologi, Fakultas Kedokteran, Universitas Kristen Maranatha \\ Jl. Prof. Drg. Suria Sumantri MPH No.65 Bandung 40164 \\ Email : hans_kristian17@yahoo.com
}

\begin{abstract}
Abstrak
Madu bunga Clover merupakan salah satu terapi herbal yang digunakan sebagai alternatif pengobatan luka. Tujuan dari penelitian adalah untuk mengetahui efek madu bunga Clover dalam mempercepat penyembuhan luka insisi, meningkatkan derajat reepitelialisasi, meningkatkan densitas fibroblas, dan meningkatkan densitas kolagen. Penelitian ini menggunakan 25 ekor tikus dibagi menjadi 5 kelompok $(\mathrm{n}=5)$, kelompok kontrol positif (feracrylum 1\%), kelompok kontrol negatif (akuades), kelompok madu 100\%, kelompok madu $50 \%$, kelompok madu 25\%. Aktivitas penyembuhan luka diukur secara makroskopis dengan jangka dan secara mikroskopis dengan preparat patologi anatomi untuk menilai derajat reepitelialisasi dan densitas kolagen. Pada pengukuran panjang luka insisi antar kelompok madu bunga Clover $100 \%, 50 \%$, 25\% didapatkan perbedaan yang signifikan dengan kelompok akuades dan feracrylum $1 \%$ ( $\mathrm{p} \leq 0.05$ ). Pada pengukuran derajat reepitelialisasi, densitas fibroblas, dan densitas kolagen antar kelompok madu bunga Clover 100\%, 50\%, 25\% didapatkan perbedaan yang signifikan dengan nilai $\mathrm{p} \leq 0.05$ dibanding dengan akuades, dan hanya kelompok madu $100 \%$ yang berbeda signifikan dibandingkan dengan feracrylum $1 \%$ ( $\mathrm{p} \leq$ 0.05). Simpulan, pemberian madu bunga Clover secara topikal mempercepat penyembuhan luka, meningkatkan derajat reepitelialisasi, densitas fibroblas, dan derajat kolagen.
\end{abstract}

Kata kunci : penyembuhan luka, derajat reepitelialisasi, densitas fibroblas, densitas kolagen, madu bunga Clover. 


\section{Research Article}

\section{Pendahuluan}

Kulit merupakan organ yang istimewa dengan berbagai fungsi dalam pemeliharaan kesehatan manusia. Secara umum kulit memiliki fungsi memberikan perlindungan fisik baik terhadap gaya mekanik, sinar ultraviolet, maupun bahan kimia. ${ }^{1}$ Kulit termasuk ke dalam sistem pertahanan tubuh bawaan (innate immunity) yang sangat sering berhubungan dengan dunia luar. ${ }^{2}$ Hal ini menyebabkan kulit akan sangat mudah terkena cedera, yang bila tidak ditangani dengan benar dapat menyebabkan komplikasi, misalnya infeksi.

Infeksi merupakan komplikasi yang berbahaya dan tersering pada penyembuhan luka, oleh karena itu pengobatan luka yang efektif dengan cara membersihkan dan menutup luka merupakan syarat mutlak untuk mempercepat proses penyembuhan dan mengurangi timbulnya jaringan parut setelah proses penyembuhan luka. ${ }^{3}$ Proses penyembuhan luka akan segera dimulai setelah timbul luka, yang diawali dengan fase hemostasis dan inflamasi, fase proliferasi, diakhiri dengan maturasi dan remodeling. ${ }^{2}$

Penelitian tentang pengobatan herbal semakin berkembang di dunia kedokteran, salah satunya penelitian-penelitian herbal yang berpengaruh terhadap proses penyembuhan luka. Pada penelitian ini zat herbal yang digunakan peneliti adalah madu. Madu telah digunakan selama berabad-abad selain untuk nutrisi juga sebagai obat. Orang Mesir kuno menggunakan madu sebagai pengobatan utama dalam berbagai hal, misalnya mengurangi rasa sakit, mempercepat penyembuhan luka, mengobati luka bakar, mengobati gigitan serangga. ${ }^{4}$

Madu merupakan bahan manis alami yang dihasilkan oleh lebah madu dari nektar bunga. ${ }^{5}$ Kandungan madu bervariasi dan bergantung dari berbagai faktor seperti sumber tanamannya dan spesies lebah yang menghasilkannya, tetapi secara umum terdiri dari $75 \%-$ $80 \%$ karbohidrat, $17 \%-20 \%$ air, dan 1\%-2\% mineral dan bahan organik lainnya. Madu mendukung metabolisme dan pencernaan, meningkatkan energi, membantu ketajaman penglihatan, meningkatkan berat badan, sebagai antioksidan, membantu dalam penyembuhan asma bronkiale dan kelainan saluran kemih, mencegah infeksi bakteri dan sebagai antiseptik yang dapat membantu penyembuhan luka, bahkan madu dapat bersifat bakterisidal poten pada beberapa kasus resisten antibiotik yang mengancam jiwa. ${ }^{4}$

Madu yang digunakan dalam penelitian ini adalah madu bunga Clover, termasuk dalam jenis madu monoflora yaitu madu yang berasal dari satu jenis tumbuhan (bunga Clover). Madu bunga Clover memiliki kandungan flavonoid dan asam fenolik (terutama P-hydroxybenzoic) yang lebih tinggi dibanding madu jenis lain. Flavonoid dan asam fenolik merupakan zat yang memiliki efek antiinflamasi dan antioksidan. ${ }^{6,7}$ Madu bunga Clover juga memiliki $\mathrm{pH}$ yang lebih rendah dibandingkan madu jenis lain. Flavonoid, asam fenolik dan $\mathrm{pH}$ rendah yang dimiliki 


\section{Research Article}

madu Clover memiliki peranan dalam membantu penyembuhan luka. ${ }^{6}$

Tujuan penelitian ini adalah mengetahui apakah pemberian madu bunga Clover secara topikal mempercepat penyembuhan luka, berdasarkan parameter makroskopis dalam bentuk percepatan penutupan luka, dan mikroskopis secara histologis dalam bentuk peningkatan derajat reepitelialisasi, densitas fibroblas, dan densitas kolagen.

\section{Metode}

Penelitian ini bersifat analitik eksperimental, dengan rancangan acak lengkap menggunakan subjek penelitian mencit Swiss-Webster jantan dewasa. Subjek penelitian yang digunakan adalah 25 ekor mencit Swiss-Webster jantan dewasa yang berumur 8 minggu dengan berat badan rata-rata 25-30 gram, yang diperoleh dari Rumah Sakit Hasan Sadikin. Sebelum penelitian dimulai, mencit diadaptasikan terlebih dahulu selama 7 hari dengan suhu ruangan dipertahankan $25 \pm 1^{\circ} \mathrm{C}$.

Metode analisis yang digunakan untuk data yang didapat dari pengukuran panjang luka insisi adalah uji ANAVA satu arah, yang dilanjutkan dengan uji post hoc LSD dengan $\alpha=0,05$. Metoda analisis untuk data derajat reepitelisasi, densitas fibroblas dan kolagen, yang dinilai dalam bentuk skoring berupa data ordinal, menggunakan uji non parametrik Kruskal-Wallis dan uji post hoc Mann Whitney U dengan $\alpha=0,05$.

Pada pelaksanaan penelitian, dibuat luka insisi menggunakan skalpel steril pada bagian punggung mencit sepanjang $2 \mathrm{~cm}$ dengan kedalaman $\pm 2 \mathrm{~mm}$. Selanjutnya, hewan coba dibagi menjadi 5 kelompok perlakuan (masing-masing kelompok terdiri dari 5 ekor mencit) yaitu kelompok kontrol positif diberi feracrylum 1\%, kelompok kontrol negatif diberi akuades, kelompok madu 100\% diberi madu bunga Clover konsentrasi 100\%, kelompok madu 50\% diberi madu bunga Clover konsentrasi 50\%, dan kelompok madu 25\% diberi madu bunga Clover konsentrasi $25 \%$. Setiap hari selama 7 hari, dilakukan pemberian topikal zat yang diujikan sekitar 0,5 ml dengan satu kali olesan di atas luka.

Setiap hari panjang luka diukur menggunakan jangka sorong dan dihitung dalam $\mathrm{mm}$. Setelah 7 hari dilakukan euthanasia aktif pada mencit dengan cara dislokasi leher, dan dilakukan pengambilan jaringan luka secara potongan memanjang. Selanjutnya, jaringan dibuat menjadi preparat patologi anatomi dan diamati parameter mikroskopik histologi yaitu peningkatan derajat reepitelialisasi, densitas fibroblas, dan densitas kolagen pada setiap kelompok hewan coba. 
Research Article

Penelitian ini dilakukan di Laboratorium Patologi/Histologi Fakultas Kedokteran Universitas Kristen Maranatha dan Laboratorium Rumah Sakit Hasan Sadikin Bandung, pada bulan Januari-Juni 2017.

Penelitian ini telah memperoleh persetujuan dari Komisi Etik Penelitian Fakultas Kedokteran Universitas Kristen Maranatha-Rumah Sakit Immanuel Bandung berdasarkan surat keputusan No 012/KEP/II/2017.

Hasil

Hasil uji ANAVA satu arah terhadap rerata panjang luka yang diukur selama 7 hari pada 25 ekor mencit Swiss-Webster jantan dewasa menggunakan bahan uji madu bunga Clover ditampilkan pada Tabel 1.

Tabel 1 ANAVA Satu Arah terhadap Rerata Panjang Luka Selama Tujuh Hari pada Setiap Kelompok Perlakuan

\begin{tabular}{lccccc}
\hline $\begin{array}{c}\text { Kelompok } \\
\text { perlakuan }\end{array}$ & $\mathrm{N}$ & $\begin{array}{c}\text { Rata-rata } \\
\text { panjang luka }\end{array}$ & $\begin{array}{c}\text { Standard } \\
\text { deviasi }\end{array}$ & F hitung & Nilai $\mathrm{p}$ \\
\hline Madu $100 \%$ & 5 & $0,87 \mathrm{~mm}$ & 0,20 & 18,73 & 0,000 \\
Madu $50 \%$ & 5 & $1,12 \mathrm{~mm}$ & 0,11 & & \\
Madu 25\% & 5 & $1,31 \mathrm{~mm}$ & 0,01 & \\
Feracrylum 1\% & 5 & $1,32 \mathrm{~mm}$ & 0,03 & \\
Akuades & 5 & $1,49 \mathrm{~mm}$ & 0,14 & & \\
\hline
\end{tabular}

Pada uji ANAVA satu arah terhadap rerata panjang luka (tabel 1) diperoleh $\mathrm{p}=0,000$, hal ini menunjukkan adanya perbedaan yang sangat signifikan pada minimal sepasang kelompok perlakuan sehingga perlu dilanjutkan dengan uji post hoc LSD untuk mengetahui signifikansi antar kelompok.

Tabel 2 Uji Post-hoc LSD terhadap Rerata Panjang Luka (dalam mm) pada Setiap Kelompok Perlakuan

\begin{tabular}{|c|c|c|c|c|c|}
\hline Kelompok & Madu $100 \%$ & Madu 50\% & Madu $25 \%$ & Feracrylum 1\% & Akuades \\
\hline Madu $100 \%$ & & $\mathrm{p}=0,005^{*} *$ & $\mathrm{p}=0,000^{*} *$ & $\mathrm{p}=0,000 * *$ & $\mathrm{p}=0,000^{*} *$ \\
\hline Madu 50\% & & & $\mathrm{p}=0,021^{*}$ & $\mathrm{p}=0,018^{*}$ & $\mathrm{p}=0,000^{* *}$ \\
\hline Madu $25 \%$ & & & & $\mathrm{p}=0,959^{\mathrm{ns}}$ & $p=0,030^{*}$ \\
\hline Feracrylum 1\% & & & & & $\mathrm{p}=0,034^{*}$ \\
\hline Akuades & & & & & \\
\hline $\begin{array}{l}\text { Keterangan: } \\
\text { ns = Non signifikan }\end{array}$ & & & $\begin{array}{l}\text { gnifik } \\
\text { ingat }\end{array}$ & ikan & \\
\hline
\end{tabular}




\section{Research Article}

Dari tabel 2 (uji post-hoc $L S D$ ) dapat dilihat perbedaan rerata panjang luka dari kelompok madu $100 \%$ dibanding feracrylum $1 \%$ menunjukkan $\mathrm{p}=0,000$, dan kelompok madu $50 \%$ dibanding feracrylum $1 \%$ menunjukkan $\mathrm{p}=0,018$. Hal ini menunjukkan bahwa antara kelompok madu $100 \%$ dan $50 \%$ dengan feracrylum $1 \%$ sebagai kontrol positif didapatkan perbedaan yang signifikan. Kelompok madu $25 \%$ dibanding feracrylum $1 \%$ diperoleh $\mathrm{p}=0,959$, hal ini menunjukkan bahwa antara kelompok madu 25\% dengan kontrol positif tidak didapatkan perbedaan yang signifikan, sedangkan antara kelompok madu 100\%, 50\%, dan 25\% dengan akuades masing-masing didapatkan perbedaan yang signifikan.

Tabel 3 Uji Kruskal-Wallis Terhadap Derajat Reepitelialisasi, Densitas Fibroblas, dan Densitas Kolagen

\begin{tabular}{ccc}
\hline Reepitelialisasi & & \\
\hline Kelompok perlakuan & Rerata skor & 0,001 \\
Madu 100\% & 21,00 & \\
Madu 50\% & 17,20 & \\
Madu 25\% & 11,50 & \\
Feracrylum 1\% & 11,80 & Nilai p \\
Akuades & 3,50 & 0,007 \\
\hline Fibroblas $\quad$ Rerata skor & \\
\hline Kelompok perlakuan & 20,50 & \\
Madu 100\% & 15,00 & \\
Madu 50\% & 12,50 & Nilai p \\
Madu 25\% & 12,50 & 0,003 \\
Feracrylum 1\% & 4,50 & \\
Akuades & & \\
\hline Kolagen $\quad$ Rerata skor & \\
\hline Kelompok perlakuan & 20,30 & \\
Madu 100\% & 16,90 & \\
Madu 50\% & 13,40 & \\
Madu 25\% & 9,90 & \\
Feracrylum 1\% & 4,50 & \\
Akuades &
\end{tabular}

Pada uji Kruskal-Wallis terhadap derajat reepitelialisasi (tabel 3) diperoleh $\mathrm{p}=0,001$; pada uji Kruskal-Wallis terhadap fibroblas (tabel 3) diperoleh $\mathrm{p}=0,007$, pada uji KruskalWallis terhadap kolagen (tabel 3) diperoleh $\mathrm{p}=0,003$. Hal ini menunjukkan adanya perbedaan yang sangat signifikan pada minimal satu pasang kelompok perlakuan sehingga perlu diuji lebih lanjut dengan uji Mann Whitney untuk mengetahui signifikansi antar kelompok. 
Tabel 4 Uji Mann Whitney terhadap Penilaian Derajat Reepitelialisasi pada Setiap Kelompok Perlakuan

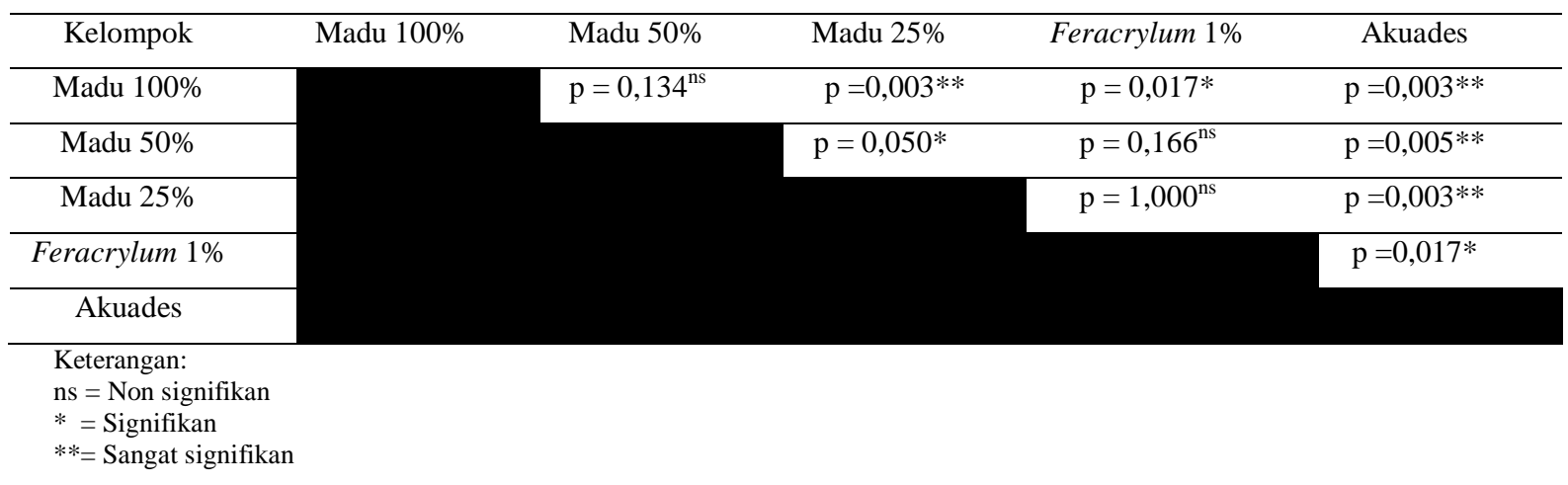

Dari tabel 4 (uji Mann Whitney) dapat dilihat perbedaan derajat reepitelialisasi dari kelompok madu 100\% dibanding feracrylum $1 \%$ diperoleh $\mathrm{p}=0,017$, hal ini menunjukkan antara kelompok madu 100\% dengan kontrol positif didapatkan perbedaan yang signifikan. Kelompok madu 50\% dibanding feracrylum 1\% diperoleh $\mathrm{p}=0,166$, hal ini menunjukkan antara kelompok madu 50\% dengan kontrol positif tidak didapatkan perbedaan yang signifikan. Kelompok madu $25 \%$ dibanding feracrylum $1 \%$ diperoleh $\mathrm{p}=1,000$, hal ini menunjukkan bahwa antara kelompok madu $25 \%$ dengan kontrol positif tidak didapatkan perbedaan yang signifikan. Sedangkan kelompok madu 100\%, 50\%, dan 25\% dibanding akuades masing-masing didapatkan perbedaan yang signifikan.

Tabel 5 Uji Mann Whitney terhadap Penilaian Densitas Fibroblas pada Setiap Kelompok Perlakuan

\begin{tabular}{l|lllll}
\hline Kelompok & Madu 100\% & Madu 50\% & Madu 25\% & Feracrylum 1\% & Akuades \\
\hline Madu 100\% & & $\mathrm{p}=0,136^{\mathrm{ns}}$ & $\mathrm{p}=0,014^{*}$ & $\mathrm{p}=0,014^{*}$ & $\mathrm{p}=0,004^{* *}$ \\
\hline Madu 50\% & & $\mathrm{p}=0,488^{\mathrm{ns}}$ & $\mathrm{p}=1,000^{\mathrm{ns}}$ & $\mathrm{p}=0,041^{*}$ \\
\hline Madu 25\% & & & $\mathrm{p}=1,000^{\mathrm{ns}}$ & $\mathrm{p}=0,015^{*}$ \\
\hline Feracrylum 1\% & & & & $\mathrm{p}=0,015^{*}$ \\
\hline Akuades & & & & \\
\hline $\begin{array}{l}\text { Keterangan: } \\
\text { ns = Non signifikan } \\
*=\text { = Signifikan } \\
* * \text { = Sangat signifikan }\end{array}$ & & & & \\
\end{tabular}

Dari tabel 5 (uji Mann Whitney) dapat dilihat perbedaan densitas kolagen dari kelompok madu $100 \%$ dibanding feracrylum $1 \%$ diperoleh $\mathrm{p}=0,014$, hal ini menunjukkan antara kelompok madu $100 \%$ dengan kontrol positif didapatkan perbedaan yang signifikan. Kelompok madu $50 \%$ dibanding feracrylum $1 \%$ diperoleh $\mathrm{p}=1,000$, hal ini menunjukkan 


\section{Research Article}

antara kelompok madu 50\% dengan kontrol positif tidak didapatkan perbedaan yang signifikan. Kelompok madu 25\% dibanding feracrylum 1\% diperoleh $\mathrm{p}=1,000$, hal ini menunjukkan bahwa antara kelompok madu 25\% dengan kontrol positif tidak didapatkan perbedaan yang signifikan. Sedangkan kelompok madu 100\%, 50\%, dan 25\% dibanding akuades masing-masing didapatkan perbedaan yang signifikan.

Tabel 6 Uji Mann Whitney Terhadap Penilaian Densitas Kolagen pada Setiap Kelompok Perlakuan

\begin{tabular}{l|ccccc}
\hline Kelompok & Madu 100\% & Madu 50\% & Madu 25\% & Feracrylum 1\% & Akuades \\
\hline Madu 100\% & & $\mathrm{p}=0,221^{\mathrm{ns}}$ & $\mathrm{p}=0,065^{\mathrm{ns}}$ & $\mathrm{p}=0, .014^{*}$ & $\mathrm{p}=0,004^{* *}$ \\
\hline Madu 50\% & & $\mathrm{p}=0,339^{\mathrm{ns}}$ & $\mathrm{p}=0,058^{\mathrm{ns}}$ & $\mathrm{p}=0,005^{* *}$ \\
\hline Madu 25\% & & & $\mathrm{p}=0,339^{\mathrm{ns}}$ & $\mathrm{p}=0,017^{*}$ \\
\hline Feracrylum 1\% & & & & $\mathrm{p}=0,050^{*}$ \\
\hline Akuades & & & & \\
\hline $\begin{array}{l}\text { Keterangan: } \\
\text { ns = Non signifikan } \\
\text { * = Signifikan } \\
\text { **= Sangat signifikan }\end{array}$ & & & & \\
\end{tabular}

Dari tabel 6 (uji Mann Whitney) dapat dilihat perbedaan densitas kolagen dari kelompok madu 100\% dibanding feracrylum $1 \%$ diperoleh $\mathrm{p}=0,014$, hal ini menunjukkan antara kelompok madu $100 \%$ dengan kontrol positif didapatkan perbedaan yang signifikan. Kelompok madu 50\% dibanding feracrylum $1 \%$ diperoleh $\mathrm{p}=0,058$, hal ini menunjukkan antara kelompok madu 50\% dengan kontrol positif tidak didapatkan perbedaan yang signifikan. Kelompok madu $25 \%$ dibanding feracrylum $1 \%$ diperoleh $\mathrm{p}=0,339$, hal ini menunjukkan bahwa antara kelompok madu $25 \%$ dengan kontrol positif tidak didapatkan perbedaan yang signifikan. Pada kelompok madu 100\%, 50\%, dan 25\% dibandingkan akuades masing-masing didapatkan perbedaan yang signifikan.

\section{Diskusi}

Pada tabel 2 dapat dilihat efek dari madu 100\%, 50\%, dan 25\% dibanding akuades sebagai kontrol negatif didapatkan perbedaan yang signifikan dengan $\mathrm{p}=0,000, \mathrm{p}=0,000$ dan $\mathrm{p}=0,030$. Hal ini menunjukan bahwa pemberian madu dapat mempercepat waktu penyembuhan dibandingkan lama penyembuhan luka pada kelompok mencit yang diberi madu luka dibanding akuades. Hal ini terjadi karena madu menekan proses inflamasi, dengan adanya kandungan flavonoid, asam fenolik mengurangi aktivitas dari enzim cyclooxygenase- 1 dan cyclooxygenase2 yang akan mengurangi pengeluaran dari mediator-mediator inflamasi seperti prostaglandin E2 


\section{Research Article}

(PGE2), prostaglandin F2 $\alpha$ (PGF2 $\alpha$ ), tromboksan B2 (TXB2). Mediator-mediator inflamasi tersebut berkurang maka terjadi inhibisi jalur Nuclear Factor-KappaB (NF- $\kappa \mathrm{B}$ ) yang berperan dalam menginduksi sitokin proinflamasi seperti interleukin 1 (IL-1), tumor necrosis factor (TNF $\alpha$ ) sehingga reaksi inflamasi akan berkurang. ${ }^{8}$

Antara kelompok perlakuan yaitu madu 100\%, 50\%, dan 25\% didapatkan perbedaan hasil dimana konsentrasi madu yang lebih tinggi memiliki efek penyembuhan luka yang lebih cepat. ${ }^{9}$ Rerata panjang luka kelompok yang diberi madu $100 \%$ dan $50 \%$ lebih kecil dibandingkan dengan kelompok yang diberi feracrylum $1 \%$ sebagai kontrol positif, menunjukkan perbedaan yang signifikan dengan $\mathrm{p}=0,000$ dan $\mathrm{p}=0,018$, hal ini berarti madu $100 \%$ dan $50 \%$ memiliki khasiat yang lebih baik dibandingkan dengan feracrylum $1 \%$ dalam mempercepat penyembuhan luka. Madu 25\% dibandingkan dengan feracrylum $1 \%$ tidak berbeda signifikan, menunjukkan bahwa madu $25 \%$ memiliki khasiat yang setara dengan feracrylum $1 \%$.

Pada pemeriksaan mikroskopis terhadap derajat reepitelialisasi, densitas fibroblas, dan densitas kolagen antara madu 100\%, 50\%, dan 25\% dibandingkan dengan akuades sebagai kontrol negatif didapatkan perbedaan yang signifikan. Hal ini membuktikan bahwa madu mempercepat penyembuhan luka yang ditinjau secara makroskopis dan mikroskopis, dilihat dari meningkatnya derajat reepitelialisasi, densitas fibroblas, dan densitas kolagen. ${ }^{9}$ Hal ini sejalan dengan penelitian Aznan,MI (2016) yang menggunakan 30 ekor tikus Wistar jantan dengan laparotomi infraumbilikal. Pemberian madu terbukti meningkatkan jumlah sel fibroblas dalam proses penyembuhan luka. ${ }^{10}$

Peningkatan derajat reepitelialisasi, densitas fibroblas, dan densitas kolagen dapat terjadi disebabkan karena madu meningkatkan transforming growth factor $\alpha$ (TGF- $\alpha$ ), IL-1 $\beta$ yang menginduksi proliferasi dari keratinosit dan fibroblas. Madu juga meningkatkan regulasi dari matrix metallo peptidase 9 (MMP-9), merupakan protease yang berperan dalam migrasi keratinosit sehingga proses reepitelialisasi berlangsung lebih cepat. ${ }^{8}$ Dari ketiga konsentrasi madu yang digunakan, hanya konsentrasi madu $100 \%$ yang berbeda signifikan dibandingkan dengan feracrylum $1 \%$ pada derajat reepitelialisasi, densitas fibroblas, dan densitas kolagen ( $\mathrm{p}=0,017, \mathrm{p}=0,014, \mathrm{p}=0,014$ secara berurutan). Hal ini menunjukkan bahwa madu $100 \%$ memiliki khasiat yang lebih baik dibanding feracrylum $1 \%$. Pemberian konsentrasi madu yang lebih tinggi menunjukkan waktu penyembuhan luka yang lebih cepat, disebabkan karena $\mathrm{pH}$ madu yg lebih asam dan kandungan gula yang lebih tinggi (efek osmolaritas) yang membantu penyembuhan luka lebih optimal. ${ }^{11}$ 


\section{Research Article}

\section{Simpulan}

Pemberian madu bunga Clover secara topikal mempercepat penyembuhan luka, meningkatkan derajat reepitelialisasi, densitas fibroblas, dan derajat kolagen.

\section{Daftar Pustaka}

1. Linuwih Sri SW Menaldi. Ilmu Penyakit Kulit dan Kelamin [Internet]. 7th ed. Bramono Kusmarinah, editor. Jakarta: Fakultas Kedokteran Universitas Indonesia; 2016. 3-5 p. Available from: www.bpfkui.com

2. F.Charles Brunicardi. Schwartz's Principles of Surgery. 10th ed. Andersen DK, editor. Llama and Alpaca Care: Medicine, Surgery, Reproduction, Nutrition, and Herd Health: First Edition. New York: McGraw-Hill Companies; 2015.p.241-164.

3. Ireland K. How to Heal Scars \& Wounds [Internet]. livestrong. 2017. [Cited 2017 Jan 10]. Available from: http://www.livestrong.com/article/117297-heal-scars-wounds/

4. Boukraa L. Honey in Traditional and Modern Medicine. Roland H, editor. Boca Raton: CRC Press; 2014. p.150-8

5. Adewumi AA, Ogunjinmi AA. The Healing Potential of Honey and Propolis Lotion on Septic Wounds. Asian Pac J Trop Biomed. 2011;1(SUPPL. 1):17-9.

6. Hamdy A a, Ismail HM, Al-Ahwal AE-M a, Gomaa NF. Determination of flavonoid and phenolic Acid contents of clover, cotton and citrus floral honeys. J Egypt Public Health Assoc [Internet]. 2009;84(3-4):245-59. [Cited 2017 Jan 10]. Available from: http://www.ncbi.nlm.nih.gov/pubmed/19889355.

7. G Vallianou N, Gounari P, Alex, Skourtis ros, Panagos J, Kazazis C. Honey and its Anti-Inflammatory, AntiBacterial and Anti-Oxidant Properties. Gen Med Open Access [Internet]. 2014;2(2):1-5. [Cited 2017 Jan 10]. Available from: http://www.esciencecentral.org/journals/honey-and-its-anti-inflammatory-anti-bacterial-and-antioxidant-2327-5146.1000132.php?aid=23335.

8. Molan P. Honey a Biologic Wound Dressing. Wounds. 2015 Jun;27(6):141-51.

9. Bregman A. Acceleration of Wound Healing by Topical Application of Honey. Am J Surg. 1983;9610(3):374-6.

10. Aznan MI, Khan OH, Unar AO, Tuan Sharif SE, Khan AH, Syed Abd Aziz SH, et al. Effect of Tualang honey on the anastomotic wound healing in large bowel anastomosis in rats-A randomized controlled trial. BMC Complement Altern Med [Internet]. 2016;16:28. [Cited 2017 Jan 10]. Available from: http://www.pubmedcentral.nih.gov/articlerender.fcgi?artid=4724403\&tool=pmcentrez\&rendertype=abstract

11. Mandal MD, Mandal S. Honey: Its medicinal property and antibacterial activity. Asian Pac J Trop Biomed. 2011;1(2):154-60. 